Resumo de Tese

\title{
Comparação da tromboelastografia com a classificação de Child-Pugh em pacientes cirróticos
}

\author{
Comparison of thromboelastography with Child-Pugh's classification in cirrbotic patients
}

Francisco R. M. Lobo

\section{Orientador:}

Renato F. da Silva

\section{Resumo}

A proposta deste estudo clínico prospectivo foi correlacionar o Tromboelastografia (TEG) com a classificação de Child-Pugh. Um total de 32 indivíduos (20 homens e 12 mulheres), idade de 8 a 62 anos, foram divididos em quatro grupos: grupo I (8 indivíduos saudáveis, grupo controle); grupo II ( 8 pacientes - Child-Pugh A); grupo III (8 pacientes - Child-Pugh $\mathrm{B})$; grupo IV (8 pacientes - Child-Pugh C).

Uma amostra de sangue foi coletada de cada indivíduo para avaliar os seguintes parâmetros: tempo de protrombina (TP), tempo de tromboplastina ativada (TTPa), relação normalizada internacional (RNI), contagem de plaquetas, fibrinogênio, íon, cálcio, albumina, bilirrubina total e TEG.

A TEG foi estatisticamente diferente quando o grupo I e grupo III foram comparados para os parâmetros $R, K$ e a, mas não foi significante para o parâmetro $A M$. Quando os grupos I e IV foram comparados, todos os parâmetros da TEG $(R, K$, a e $A M)$ mostraram significância estatística.

Nós concluímos que houve uma correlação entre a TEG dos indivíduos do grupo I (controle) e a TEG dos pacientes do grupo III (Child-Pugh B) para os parâmetros $R, K$, a e uma correlação entre a TEG dos indivíduos do grupo I (saudáveis) com a TEG dos pacientes do grupo IV (Child-Pugh C) para todos os parâmetros. Assim, a TEG não se correlaciona com a classificação de Child-Pugh como um indicador de gravidade de doença crônica hepática.

\begin{abstract}
The purpose of this prospective clinical study was to correlate the Thromboelastography (TEG) with the Child-Pugh's classification. A lof 32 subjects ( 20 male and 12 female), with ages ranging from 8 to 62 years, were divided into 4 groups: group I ( 8 healthy, control patients); group II ( 8 patients Child-Pugh A); group III (8 patients - Child-Pugh $B)$; and group IV (8 patients - Child-Pugh C).

A blood sample was collected from the subjects to evaluate the following parameters: prothrombin time (PT), activated partial thromboplastin time (apt), international normalized relation (INR), platelet count, fibrinogen, ion calcium, albumin, total bilirubin and TEG.

The TEG had statistical differences when group I and group III were compared for the parameters $R, K$ e a, but the difference was not significant for $A M$. When group I (control group) and group IV (Child-Pugh C) were compared, all TEG parameters ( $R, K, a$ and $M A$ ) showed statistical significance.

We concluded there was a correlation between TEG of group I (control) and group III (Child-Pugh B) for the parameters $R, K e a$, and a correlation between TEG of group I (control) and group IV (Child-Pugh C) for all parameters. However, TEG does not correlate with ChildPugh's classification as an indicator of the severity of chronic liver disease.
\end{abstract}

Recebido: 15/05/01

Aceito: 18/06/01

Tese de dissertação para obtenção do título de mestre em Ciências da Saúde, Área de Concentração: Medicina Interna na Faculdade de Medicina de Saõ José do Rio Preto, FAMERP, SP 